\title{
Digital necrosis in an infant with severe spinal muscular atrophy
}

Diana Carrasco, MD, Pilar Magoulas, MS, CGC, Jennifer C. Scull, PhD, Jill A. Jarrell, MD, MPH, Seema R. Lalani, MD, and Michael F. Wangler, MD

Neurol Genet 2019;5:e361. doi:10.1212/NXG.0000000000000361

\author{
Correspondence \\ Dr. Wangler \\ michael.wangler@bcm.edu
}

Spinal muscular atrophy (SMA) is the leading genetic cause of death for infants. ${ }^{1,2}$ Digital necrosis is an ultra-rare manifestation of this disease, and its etiology has yet to be elucidated. ${ }^{4,5}$ We present a child who was referred to genetics for extensive digital necrosis after cardiac surgery. The infant was ultimately diagnosed with SMA by single gene testing that revealed a homozygous deletion of exons 7 and 8 on the SMN1 gene. SMA is a motor neuron disorder typically presenting with neurologic symptoms but should be considered in any infant with digital necrosis.

\section{Case report}

The child was born uneventfully to a family with an unremarkable medical history. At age 1 month, he presented with failure to thrive. Workup revealed a large atrial septal defect and multiple ventricular septal defects. Pulmonary artery banding was performed at age 2 months. Postoperatively, he required intubation for 3 weeks. He also developed severe necrosis of all 10 toes (figure, A). A hypercoagulation panel was normal. A Doppler ultrasound revealed a left femoral clot, which was successfully treated with anticoagulation, aspirin, and nitroglycerin. However, the necroses progressed, and no cause was initially identified. Allowing autoamputation of the toes was recommended. He was discharged home at age 4 months on gastrostomy tube feeds. By then, developmental delay was noted, although he was able to roll from his stomach to his back and bring his hands to his mouth. At home, he started having respiratory problems, with oxygen saturations in the mid 80 s. He intermittently developed diaphoresis and tachypnea.

He was readmitted 1.5 weeks later. His mother had additionally noticed a violaceous discoloration of his fingernails (figure, B). Despite heparin, aspirin, methylprednisolone (in case of vasculitis), and a supraclavicular nerve block with the intent of reversing any vasoconstriction, this progressed to severe necrosis. CT angiography and an echocardiogram did not reveal an embolic source. At that time, the child was also found to have clinically recognizable hypotonia, decreased right palmar grasp strength, and a tremulous tongue. On the day of readmission, he went into respiratory failure requiring intubation. A workup for rheumatologic conditions returned negative including an antiphospholipid panel, antinuclear antibodies, cryoglobulin levels, anti-neutrophil cytoplasmic antibodies for myeloperoxidase, anti-neutrophil cytoplasmic antibodies for proteinase 3, adenosine deaminase 2 deficiency, and a cytokine panel. A brain MRI returned normal. Trio wholeexome sequencing was sent, and results were nondiagnostic. An electromyogram demonstrated evidence of possible anterior horn cell dysfunction as can be seen in SMA. SMN1 genetic testing was sent, and PCR amplification showed a homozygous deletion of exons 7 and 8, diagnostic of SMA. In addition, the SMN2 copy number was tested revealing that the patient had only 1 copy of SMN2. The pediatric palliative care team helped elucidate the family's goals for the patient, facilitated a comfort care plan, which included a compassionate extubation, and continued to provide bereavement support for the family. 


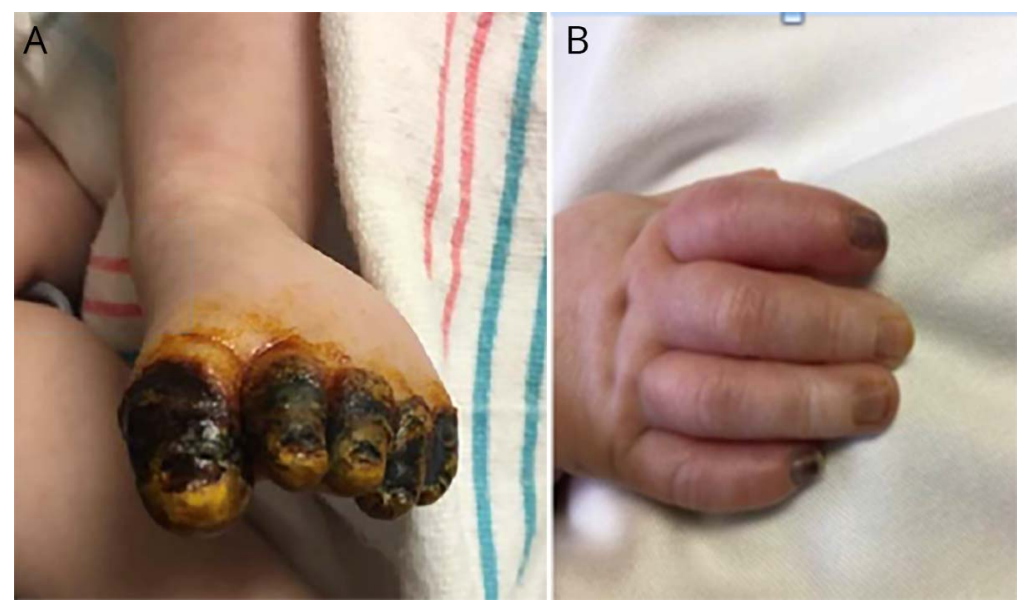

(A) Left foot. (B) Right hand.

\section{Discussion}

SMA is a result of biallelic intragenic deletions or pathogenic variants in the SMN1 gene located on chromosome 5q13, which cause loss of function of the survival of motor neuron protein (SMN). SMN is ubiquitously expressed, and although SMA is characterized by loss of motor neurons in the ventral horn of the spinal cord, multiple organs, including cardiac, skeletal, and gastrointestinal, are negatively affected as well. ${ }^{2,3}$ The severity and age at onset span a continuum. Digital necrosis is rare in SMA and has been reported in only 4 other cases, all infants with a severe form of the disease. ${ }^{4,5}$ Of interest, mouse models for severe SMA given life-prolonging treatments have developed tail and ear necrosis. ${ }^{6}$ The SMN2 gene is nearly identical to the $S M N 1$ gene except for a single nucleotide change, which causes skipping of its exon 7 , resulting in only $10 \%$ of its protein product being functional. The copy number of SMN2 varies in the population and inversely correlates with disease severity. In our case, the patient was found to have only 1 copy of SMN2. The antisense oligonucleotide nusinersen was approved for treatment of certain cases of SMA. Nusinersen increases the percentage of $S M N 2$ 's functional protein product by including transcription of its exon 7 . $^{7}$ This along with other interventions is expected to improve life expectancy. Our patient presented before the approval of this medication, and it is not known whether a manifestation such as a digital necrosis would respond to this new therapy. Further delineation of the phenotype of SMA will aid in uncovering etiologies of the disease's manifestations and directed therapies. This report describes the fifth case of an infant with severe SMA who developed distal digital necrosis. An examination of SMN2 copy number in more of these cases with this unusual and dramatic complication would be useful. Our case highlights the need to consider SMA in the differential diagnosis for infantile digital necrosis.

\section{Study funding}

No targeted funding reported.

\section{Disclosure}

Disclosures available: Neurology.org/NG.

\section{Publication history}

Received by Neurology: Genetics April 30, 2019. Accepted in final form August 12, 2019.

\begin{tabular}{|c|c|c|c|}
\hline Name & Location & Role & Contribution \\
\hline $\begin{array}{l}\text { Diana } \\
\text { Carrasco, } \\
\text { MD }\end{array}$ & $\begin{array}{l}\text { Department of Molecular and } \\
\text { Human Genetics, Baylor } \\
\text { College of Medicine, Houston, } \\
\text { TX }\end{array}$ & Author & $\begin{array}{l}\text { Drafting and } \\
\text { revision }\end{array}$ \\
\hline $\begin{array}{l}\text { Pilar } \\
\text { Magoulas, } \\
\text { MS, CGC }\end{array}$ & $\begin{array}{l}\text { Department of Molecular and } \\
\text { Human Genetics, Baylor } \\
\text { College of Medicine; Texas } \\
\text { Children's Hospital, Houston, } \\
\text { TX }\end{array}$ & Author & $\begin{array}{l}\text { Drafting and } \\
\text { revision }\end{array}$ \\
\hline $\begin{array}{l}\text { Jennifer C. } \\
\text { Scull }\end{array}$ & $\begin{array}{l}\text { Department of Molecular and } \\
\text { Human Genetics, Baylor } \\
\text { College of Medicine, Houston, } \\
\text { TX }\end{array}$ & Author & $\begin{array}{l}\text { Revision and } \\
\text { molecular } \\
\text { diagnostics }\end{array}$ \\
\hline $\begin{array}{l}\text { Jill Ann } \\
\text { Jarrell, } \\
\text { MD, MPH }\end{array}$ & $\begin{array}{l}\text { Texas Children's Hospital, } \\
\text { Houston, TX }\end{array}$ & Author & $\begin{array}{l}\text { Drafting and } \\
\text { revision }\end{array}$ \\
\hline $\begin{array}{l}\text { Seema } \\
\text { Lalani, MD }\end{array}$ & $\begin{array}{l}\text { Department of Molecular and } \\
\text { Human Genetics, Baylor } \\
\text { College of Medicine, Houston, } \\
\text { TX }\end{array}$ & Author & $\begin{array}{l}\text { Drafting and } \\
\text { revision }\end{array}$ \\
\hline $\begin{array}{l}\text { Michael F. } \\
\text { Wangler, } \\
\text { MD }\end{array}$ & $\begin{array}{l}\text { Department of Molecular and } \\
\text { Human Genetics, Baylor } \\
\text { College of Medicine, Houston, } \\
\text { TX }\end{array}$ & Author & $\begin{array}{l}\text { Drafting and } \\
\text { revision }\end{array}$ \\
\hline
\end{tabular}




\section{References}

1. Sugarman EA, Nagan N, Zhu H, et al. Pan-ethnic carrier screening and prenatal diagnosis for spinal muscular atrophy: clinical laboratory analysis of $>72,400$ specimens. Eur J Hum Genet 2012:27-32.

2. Shababi M, Lorson CL, Rudnik-Schoneborn SS. Spinal muscular atrophy: a motor neuron disorder or a multi-organ disease? J Anat 2014;224:15-28.

3. Sintusek P, Catapano F, Angkathunkayul N, et al. Histopathological defects in intestine in severe spinal muscular atrophy mice are improved by systemic antisense oligonucleotide treatment. PLoS One 2016;11:e0155032.
4. Araujo AQ, Araujo M, Swoboda KJ. Vascular perfusion abnormalities in infants with spinal muscular atrophy. J Pediatr 2009;155:292-294.

5. Rudnik-Schoneborn S, Vogelgesang S, Armbrust S, Graul-Neumann L, Fusch C, Zerres K. Digital necroses and vascular thrombosis in severe spinal muscular atrophy. Muscle Nerve 2010;42:144-147.

6. Narver HL, Kong L, Burnett BG, et al. Sustained improvement of spinal muscular atrophy mice treated with trichostatin A plus nutrition. Ann Neurol 2008;64: 465-470.

7. Wurster CD, Ludolph AC. Nusinersen for spinal muscular atrophy. Ther Adv Neurol Disord 2018;11:1756285618754459. 


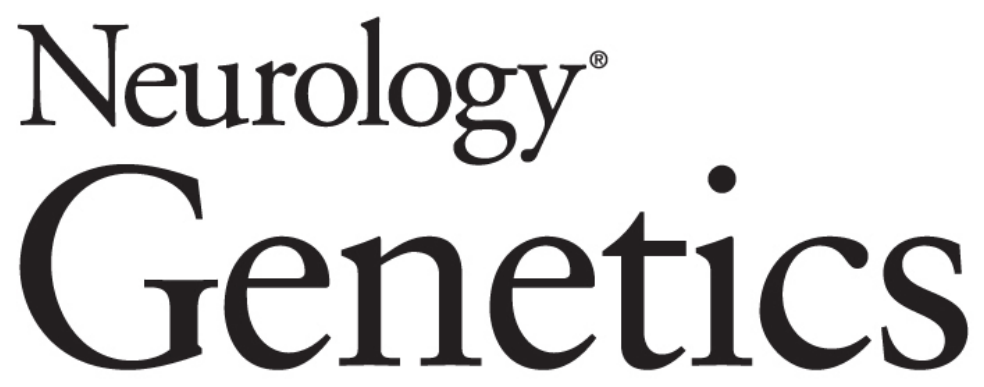

Digital necrosis in an infant with severe spinal muscular atrophy

Diana Carrasco, Pilar Magoulas, Jennifer C. Scull, et al. Neurol Genet 2019;5;

DOI 10.1212/NXG.0000000000000361

This information is current as of September 23, 2019

Neurol Genet is an official journal of the American Academy of Neurology. Published since April 2015, it is an open-access, online-only, continuous publication journal. Copyright Copyright () 2019 The Author(s). Published by Wolters Kluwer Health, Inc. on behalf of the American Academy of Neurology.. All rights reserved. Online ISSN: 2376-7839.

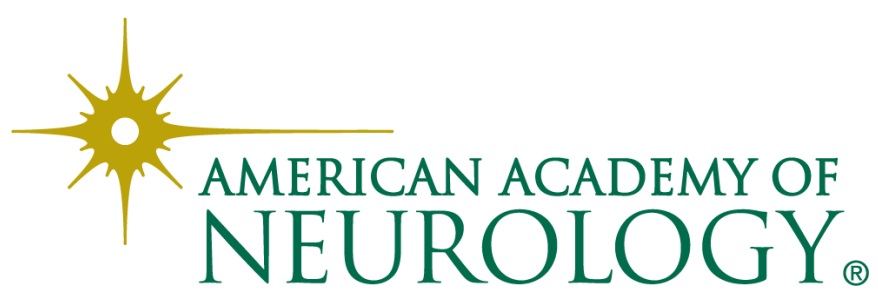




\section{Updated Information \& Services}

References

Subspecialty Collections

Permissions \& Licensing

Reprints including high resolution figures, can be found at:

http://ng.neurology.org/content/5/5/e361.full.html

This article cites 6 articles, 0 of which you can access for free at: http://ng.neurology.org/content/5/5/e361.full.html\#\#ref-list-1

This article, along with others on similar topics, appears in the following collection(s):

\section{All Genetics}

http://ng.neurology.org//cgi/collection/all_genetics

All Pediatric

http://ng.neurology.org//cgi/collection/all_pediatric

Clinical neurology examination

http://ng.neurology.org//cgi/collection/clinical_neurology_examination

Muscle disease

http://ng.neurology.org//cgi/collection/muscle_disease

Neonatal

http://ng.neurology.org//cgi/collection/neonatal

Information about reproducing this article in parts (figures,tables) or in its entirety can be found online at:

http://ng.neurology.org/misc/about.xhtml\#permissions

Information about ordering reprints can be found online:

http://ng.neurology.org/misc/addir.xhtml\#reprintsus

Neurol Genet is an official journal of the American Academy of Neurology. Published since April 2015, it is an open-access, online-only, continuous publication journal. Copyright Copyright $\odot 2019$ The Author(s). Published by Wolters Kluwer Health, Inc. on behalf of the American Academy of Neurology.. All rights reserved. Online ISSN: 2376-7839.

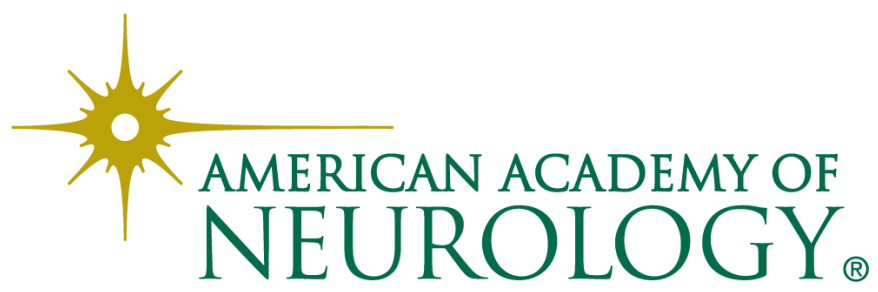

